\title{
PENINGKATAN HASIL BELAJAR IPA DENGAN MENERAPKAN MODEL CONTEXTUAL TEACHING AND LEARNING (CTL) MATERI PENERAPAN KONSEP ENERGI GERAK PADA SISWA KELAS III SEKOLAH DASAR NEGERI 3 NGABENREJO GROBOGAN
}

\author{
Sri Martini \\ Sekolah Dasar Negeri 3 Ngabenrejo Kecamatan Grobogan Kabupaten Grobogan
}

\begin{abstract}
study aims to improve the ability to learn science in learning science in class III SD Negeri 3 Ngabenrejo through the Contextual teaching and learning learning model. This research is a classroom action research where the researcher works together with peers as observers in conducting research. The subjects of the study were grade III students of SD Negeri 3 Ngabenrejo, as many as 22 students consisting of 6 male students and 16 female students. The data analysis technique used is qualitative descriptive analysis for the observations of each cycle and quantitative descriptive analysis to analyze the test results for each cycle. The study was conducted in 2 cycles. The results showed that the use of CTL learning models can improve the ability of science learning outcomes in class III SD Negeri 3 Ngabenrejo. This is indicated by an increase in value from before giving action to cycle II. The average value of the class obtained by students before the action was 57 , in the first cycle, the average value of 70 in the second cycle, the value the average obtained was 85.68. The conclusion of using the CTL learning model can improve the ability to learn science in learning science class III SD Negeri 3 Ngabenrejo
\end{abstract}

Keywords: Learning Outcomes, Contextual teaching and learning, Motion Energy

\begin{abstract}
ABSTRAK
Penelitian ini bertujuan untuk meningkatkan kemampuan Hasil Belajar IPA pada pembelajaran IPA di kelas III SD Negeri 3 Ngabenrejo melalui model pembelajaran Contextual teaching and learning. Penelitian ini merupakan penelitian tindakan kelas dimana peneliti bekerja sama dengan teman sejawat sebagai observer pada pelaksanaan penelitian. Subjek penelitian adalah siswa kelas III SD Negeri 3 Ngabenrejo, sebanyak 22 siswa terdiri dari 6 siswa putra dan 16 siswa putri. Teknik analisis data yang digunakan adalah analisis deskriptif kualitatif untuk hasil observasi setiap siklus dan analisis deskriptif kuantitatif untuk menganalisis hasil tes setiap siklus. Penelitian dilaksanakan dalam 2 siklus. Hasil penelitian menunjukan bahwa penggunaan model pembelajaran CTL dapat meningkatkan kemampuan hasil belajar IPA di kelas III SD Negeri 3 Ngabenrejo. Hal ini ditunjukan dengan adanya peningkatan nilai dari sebelum pemberian tindakan hingga siklus II. Nilai rata-rata kelas yang diperoleh siswa sebelum tindakan adalah 57,04 pada siklus I, nilai rata-rata 70 Pada siklus II, nilai rata-rata yang diperoleh adalah 85,68. Kesimpulan penggunaan model pembelajaran CTL dapat meningkatkan kemampuan hasil belajar IPA pada pembelajaran IPA kelas III SD Negeri 3 Ngabenrejo.
\end{abstract}

Kata Kunci: Hasil Belajar, Contextual teaching and learning, Penerapan Konsep Energi Gerak

\footnotetext{
${ }^{1)}$ Korespondensi : Dalilatul Kasanah, SDN 4 Kedunggebang . Kec.Tegaldlimo, Kab. Banyuwangi Email : dalilatul.yakub@gmail.com

${ }^{2)}$ Korespondensi : Moh Luqman Hakim, Program Studi PGSD Fakultas Ilmu Pendidikan Universitas Trunojoyo Madura Email : luqmanhyacob@gmail.com
} 


\section{PENDAHULUAN}

Pembelajaran merupakan kegiatan yang dilakukan seseorang untuk mendapatkan pengetahuan dan keterampilan baru dari lingkungannya. Dalam proses pembelajaran di sekolah dasar terdapat beberapa mata pelajaran yang mengacu pada kurikulum yang berlaku. Dalam setiap mata pelajaran tersebut, terdapat beberapa kompetensi yang harus dikuasai dan dipahami oleh siswa. Salah satu mata pelajaran di Sekolah Dasar adalah mata pelajaran Ilmu Pengetahuan Alam (IPA) dapat diartikan sebagai "Ilmu yang mempelajari tentang sebab dan akibat kejadian-kejadian yang ada di alam ini”. (Wisudawati \& Sulistyowati, 2013: 23). Jadi IPA merupakan ilmu yang mempelajari tentang fenomena alam atau ilmu yang berkaitan erat dengan kehidupan.

Pembelajaran IPA memegang peranan yang penting didalam upaya mewujudkan sikap yang mencerminkan kepribadian yang dapat menjaga dan melestarikan lingkungan atau alam sekitar. Sebagai salah satu mata pelajaran yang memegang peranan penting, maka perlu adanya kerjasama antara siswa dan guru untuk meningkatkan keberhasilan pendidikan. Namun, di Indonesia masih terdapat berbagai masalah yang dihadapi pada proses pembelajaran IPA hal ini diperkuat oleh yang dikemukakan oleh Hayat dan Yusuf, (Wisudawati \& Sulistyowati, 2013: 48) "Hasil belajar IPA yang dicapai oleh siswa di Indonesia yang tergolong rendah dipengaruhi oleh banyak faktor,yaitu karakteristik siswa dan keluarga, kemampuan membaca, motivasi belajar, minat dan konsep diri, strategi belajar, tingkat kehadiran dan rasa memiliki”. Permasalahan tersebut di SDN 3 Ngabenrejo seringkali dijumpai ketika proses pembelajaran masih terdapat beberapa siswa yang memiliki hasil belajar rendah, hal ini diperoleh dari nilai harian siswa kelas III SDN 3 Ngabenrejo bahwa dari jumlah 22 siswa terdapat 13 orang siswa yang memperoleh nilai di bawah Kriteria Ketuntasan Minimal (KKM) dengan nilai terendah yang diperoleh siswa yaitu 25 , hal ini berarti bahwa siswa yang tuntas mencapai KKM hanya 40,9\%. Sehingga dapat dikatakan bahwa kurangnya pemahaman siswa terhadap materi yang berdampak pada hasil belajar siswa. Selain itu, model pembelajaran kurang bervariatif dan sarana prasarana kurang memadai sehingga proses pembelajaran berdampak pada hasil belajar siswa dan siswa kurang berpartisipasi secara aktif baik secara fisik 
maupun mental sehingga menimbulkan kejenuhan siswa dalam belajar.

Berdasarta fakta lapangan yang ada tersebut, maka semua pihak di lembaga sekolah hendaknya memperhatikan hal itu yang kemudian perlu adanya inovasi dalam proses pembelajaran melalui sebuah model pembelajaran. Menurut Wisudawati \& Sulistyowati (2013: 48) "Model pembelajaran merupakan kerangka konseptual yang melukiskan prosedur secara sistematis dalam mengorganisasikan pengalaman belajar untuk mencapai tujuan pembelajaran”. Melalui penerapan model pembelajaran Contextual teaching and learning (CTL) maka dalam pembelajaran dapat membuat siswa menerapkan dan mengalami apa yang sedang diajarkan dengan mengacu pada masalah-masalah dunia nyata, sehingga pembelajaran akan menjadi lebih

\section{METODE PENELITIAN}

Kegiatan penelitian tindakan kelas ini dilaksanakan di SD Negeri 3 Ngabenrejo kecamatan Grobogan kabupaten Grobogan pada semester 2 tahun ajaran 2017/2018. Penelitian dilaksanakan dari bulan Januri sampai akhir bulan Maret. Karena peneliti menyesuaikan dengan kondisi di lapangan dimana pada awal Januari proses berarti dan menyenangkan. Siswa menggunakan pengalaman dan pengetahuan sebelumnya untuk membangun pengetahuan baru. Oleh karena itu, model pembelajaran Contextual teaching and learning (CTL) berhasil karena model ini menghubungkan materi dengan konsep dunia nyata.

Dari hasil pemaparan diatas maka dapat disimpulkan model pembelajaran merupakan suatu pola dalam pembelajaran yang disusun secara sistematis untuk mencapai tujuan pembelajaran. Pemaparan diatas memberikan inspirasi kepada penulis untuk mencoba melakukan penelitian dengan mengangkat judul "Penerapan Model Pembelajaran Contextual teaching and learning (CTL) Terhadap Hasil Belajar Siswa Pada Mata Pelajaran IPA Kelas III SDN 3 Ngabenrejo”.

pembelajaran di sekolah SD sudah memasuki ajaran baru. Untuk Siklus I dilaksanakan 2 tindakan yaitu tindakan I Senin, 5 Februari 2018 dan tindakan II Jumat, 9 Februari 2018. Untuk Siklus II dilaksanakan 2 tindakan yaitu tindakan I Senin, 12 Februari 2018 dan tindakan II Jumat, 16 Februari 2018.

Penelitian tindakan kelas ini dilaksanakan di SD Negeri 3 Ngabenrejo 
yang terletak di Desa Ngabenrejo Kecamatan Grobogan Kabupaten Grobogan yang dipimpin oleh Juwadi, S.Pd.. penelitian dilakukan di kelas III, sebanyak 22 siswa, yang terdiri atas 6 siswa laki-laki dan 16 siswa perempuan dengan wali kelas Sri Martini, S.Pd.SD. Pemilihan kelas III didasarkan pada permasalahan yaitu pada pembelajaran IPA di SD Negeri 3 Ngabenrejo kelas III masih menggunakan model konvensional dimana guru hanya memberikan penjelasan saja dalam menyampaikan materi sehingga siswa tidak memahami konsep dari materi yang diajarkan kemudian hasil belajar siswa pada kelas III SD Negeri 3 Ngabenrejo masih rendah. Kelas III merupakan kelas rendah yang seharusnya sudah memiliki dasar mengenai materi Penerapan Konsep Energi Gerak.

Subjek dalam penelitian ini adalah siswa kelas III SD Negeri 3 Ngabenrejo tahun ajaran 2017/2018. Jumlah siswa di kelas tersebut adalah 22 siswa, terdiri dari 6 putra dan 16 putri. Data penelitian yang akan dikumpulkan berupa peristiwa dan informasi tentang proses pembelajaran pada mata pelajaran IPA, untuk meningkatkan hasil belajar siswa. Sumber data yang diperoleh dari siswa dan guru kelas III SDN 3 Ngabenrejo tahun ajaran
2017/2018 Kec. Grobogan Kab. Grobogan untuk mengetahui seberapa besar peningkatan hasil belajar siswa terhadap mata pelajaran IPA setelah menggunakan metode Contextual teaching and learning (CTL).

\section{HASIL DAN PEMBAHASAN}

Deskripsi hasil penelitian per siklus berupa deskripsi hasil identifikasi dan perumusan masalah, akan peneliti uraikan secara singkat tentang langkah - langkah perbaikan yang telah direncanakan dalam 2 siklus. Setiap siklus terdiri dari empat tahapan yaitu : perencanaan, pelaksanaan, pengamatan, dan refleksi.

Deskripsi kondisi awal

Temuan dari hasil observasi ditemukan suatu permasalahan yaitu:

a. Pada pembelajaran IPA di SD Negeri 3 Ngabenrejo disajikan pembelajaran yang bentuknya konvensional

b. Dalam proses pembelajaran menggunakan metode ceramah untuk menyampaikan materi pembelajaran IPA

c. kemampuan Hasil belajar siswa masih rendah khususnya pada pembelajaran IPA

Dari hasil penelitian awal bahwa dari 22 orang siswa yang mengikuti tes awal tentang Materi Penerapan Konsep 
Energi Gerak mencapai ketuntasan klasikal $40,9 \%$ dengan rata-rata nilai yaitu 57,04 jadi hanya 9 orang siswa yang dapat mencapai nilai ketuntasan belajar yang telah ditentukan, jadi ada 13 orang siswa yang belum bisa mencapai ketuntasan belajar khususnya pada Hasil belajar. Hal ini mengandung arti bahwa proses pembelajaran IPA tersebut belum memenuhi standar yang ditetapkan, sehingga diperlukan tindakan nyata untuk memperbaikinya, masih banyak siswa yang kurang mampu dalam menjawab soal-soal Materi Penerapan Konsep Energi Gerak dikarenakan oleh beberapa masalah ketika mereka menerima materi saat proses pembelajaran sehingga mereka tidak mampu untuk mengolah Hasil belajar tentang materi yang telah mereka terima dengan menjelaskan oleh bahasa mereka sendiri. Oleh karena itu peneliti merasa harus adanya perbaikan dari hasil kondisi awal yang memang Hasil belajar IPA siswa masih rendah khususnya pada Materi Penerapan Konsep Energi Gerak kelas III di SD Negeri 3 Ngabenrejo penulis merencanakan perbaikan pembelajaran pada siklus I.

\section{A. Siklus I}

1. Data tentang perencanaan

Kegiatan perencanaan siklus I tindakan I dilaksanakan pada hari Senin, 5
Februari 2018 di kelas III SD Negeri 3 Ngabenrejo, peneliti membuat rancangan penelitian tindakan yaitu berupa Rencana Pelaksanaan Pembelajaran yang akan dilakukan dalam penelitian ini. Berdasarkan hasil observasi dan pengamatan bahwa siswa kurang dalam memahami Materi Penerapan Konsep Energi Gerak sehingga Hasil belajar pada pembelajaran IPA masih kurang, untuk mengatasi hal tersebut peneliti akan membuat suatu perencanaan proses pembelajaran yang baru dengan mengguanakan model contextual teaching and learning dalam pembelajaran.

2. Data tentang pelaksanaan

$$
\text { Pelaksanaan perbaikan }
$$
pembelajaran dibantu oleh teman sejawat dengan persetujuan Kepala Sekolah tempat penelitian dilakukan. Hasil tabel diatas bahwa observasi tindakan I diperoleh hasil aktivitas guru dalam proses pembelajaran dari beberapa aspek yang telah direncanakan sebelumnya masih ada kekurangan guru yang harus diperbaiki dalam melaksanakan proses pembelajaran pada tindakan I yaitu pada langkah 5 pada saat guru menyampaikan tujuan pembelajaran guru masih kurang jelas dalam penyampaian tujuan pembelajarannya, kemudian langkah 6 dalam proses tanya jawab untuk menggali 
pengetahuan awal siswa guru kurang memberikan motivasi kepada siswa sehingga siswa kurang termotivasi untuk mengikuti pembelajaran dan masih banyak siswa yang pasif tidak bertanya maupun menjawab pertanyaan dari guru. Langkah 8 dalam menjelaskan langkah-langkah untuk melakukan percobaan guru tidak jelas dalam memberikan langkah-langkah untuk percobaan sehingga siswa bingung dalam mengerjakan percobaan tersebut. Langkah 9 dalam mengelompokkan siswa menjadi 4 kelompok dengan jumlah masing-masing kelompok 5-6 orang siswa masih mengalami kesulitan yaitu siswa ribut saat pembagian kelompok diskusi sehingga kelas tidak kondusif, langkah 12 dalam membimbing kelompok guru dalam memberikan bimbingan harus lebih interaktif dengan siswa yang lain tidak fokus hanya ke beberapa siswa saja. Langkah 13 dalam memberikan tugas kepada siswa untuk menyampaikan hasil diskusi guru tidak jelas dalam pemberian tugas sehingga siswa tidak paham dalam penyampaian hasil diskusi tersebut, selanjutnya yaitu langkah 16 dalam menyimpulkan pembelajaran guru masih menyimpulkan pembelajaran sendiri dan siswa tidak ikut menyimpulkan hasil dari pembelajaran yang sudah dilakukan. Jadi dari beberapa kekurangan aktivitas guru dalam tindakan I ini masih perlu perbaikan dalam proses pembelajaran dan diperbaiki dalam tindakan selanjutnya.

Siswa dalam proses pembelajaran masih belum bisa mandiri, sebagian besar siswa pasif belum bisa bertanya untuk menanyakan hal yang tidak dipahami, belum bisa menemukan sendiri apa yang sedang mereka pelajari dan belum bisa menentukan konsep materi yang sedang dibahas sehingga pada proses pembelajaran siswa sulit dalam menjelaskan apa yang mereka pelajari. Siswa masih belum bisa memprediksi nilai yang akan mereka dapat karena mereka kurang aktif dalam proses pembelajarannya, hanya ada beberapa orang saja yang terlihat aktif. Jadi dalam tindakan I ini aktivitas siswa masih banyak yang harus diperbaiki dan ditingkatkan lagi dalam tindakan selanjutnya.

Kegiatan perencanaan siklus I tindakan II dilaksanakan pada hari Jumat, 9 Februari 2018 di kelas III SD Negeri 3 Ngabenrejo, peneliti membuat rancangan penelitian tindakan yaitu berupa Rencana Pelaksanaan Pembelajaran yang akan dilakukan dalam penelitian ini. Berdasarkan hasil reflekai pada tindakan I bahwa masih banyak siswa yang belum mencapai target ketuntasan dan memerlukan suatu perbaikan, sehingga 
peneliti akan membuat suatu perencanaan proses pembelajaran yang dapat meningkatkan hasil dari proses pembelajaran siswa.

Setelah peneliti menyusun perencanaan untuk penelitian, selajutnya peneliti harus melaksanakan semua rencana yang telah disusun dengan baik dan harus sesuai dengan rancangan pembelajaran yang telah dibuat sedemikian rupa agar semua tujuan dapat tercapai.

\section{B. Siklus II}

\section{Data tentang perencanaan}

Perencanaan siklus II merupakan perbaikan dari tindakan-tindakan siklus I. Perencanaan siklus II akan dilaksanakan dua tindakan dengan diberikan soal evaluasi pada akhir siklus untuk mengetahui tingkat keberhasilan, kekurangan dan kelebihan dari pelaksanaan tindakan tersebut. Perencanaan kegiatan setiap tindakan dengan alokasi waktu 2x35 dan 3x35 menit dalam meningkatkan Hasil belajar IPA pada pembelajaran IPA dengan menggunakan model Contextual teaching and learning. Pelaksanaan siklus II tindakan I dan II yaitu membahas materi yang direncanakan yaitu Penerapan Konsep Energi Gerak.

Setelah peneliti menyusun perencanaan untuk penelitian, selajutnya peneliti harus melaksanakan semua rencana yang telah disusun dengan baik dan harus sesuai dengan rancangan pembelajaran yang telah dibuat sedemikian rupa agar semua tujuan dapat tercapai.

Dalam hasil pengamatan aktivitas guru dan siswa serta temuan essensial masih banyak hal yang harus diperbaiki pada tahap tindakan pembelajaran selanjutnya. Perbaikan tersebut akan dipaparkan pada tahap refleksi. Interaksi antara guru dengan siswaa dan siswa dengan siswa sudah terjalin, mampu bekerja sama dengan siswa yang lain dalam kelompok unutk bertukar pendapat mengenai Materi Penerapan Konsep Energi Gerak, mampu menyampaikan hasil dari pembelajaran, mampu menyimpulkan materi yang telah dipelajari dan memunculkan rasa keingintahuan yang tinggi. Tindakan I dalam proses pembelajaran sebagian siswa sudah mulai mengikuti pembelajaran yang direncanakankemudian siswa sudah mulai berinteraksi dengan baik. Tindakan I ini siswa masih ada kekurangan yaitu ada siswa yang tidak mencapai nilai ketuntasan yang telah ditentukan, hal ini mengandung arti bahwa dalam tindakan I tersebut belum memenuhi standar yang ditetapkan, sehingga diperlukan tindakan selanjutnya untuk memperbaikinya. 
Kegiatan perencanaan siklus II tindakan II dilaksanakan pada hari Jumat, 16 Februari 2018 di kelas III SD Negeri 3 Ngabenrejo, peneliti membuat rancangan penelitian tindakan yaitu berupa Rencana Pelaksanaan Pembelajaran yang akan dilakukan dalam penelitian ini. Berdasarkan hasil reflesi pada tindakan I bahwa masih memerlukan suatu perbaikan, sehingga peneliti akan membuat suatu perencanaan proses pembelajaran yang dapat meningkatkan hasil dari proses pembelajaran siswa.

Setelah peneliti menyusun perencanaan untuk penelitian, selajutnya peneliti harus melaksanakan semua rencana yang telah disusun dengan baik dan harus sesuai dengan rancangan pembelajaran yang telah dibuat sedemikian rupa agar semua tujuan dapat tercapai, adapun langkah-langkah proses pembelajarannya yaitu proses pembukaan dengan waktu 10 menit guru mulai membuka pembelajaran kemudian bersama dengan siswa untuk memulai pembelajaran diawali dengan berdo'a bersama-sama, kemudian guru mengecek kehadiran siswa dan guru terlebih dahulu menyampaikan apersepsi berupa pertanyaan yang disampaikan dengan cara tanya jawab langsung dengan siswa sebagai langkah awal untuk menggali pengetahuan awal siswa agar siswa mendapat motivasi dan semangat mengikuti pembelajaran.

\section{Hasil Tes Pra Siklus, Siklus I dan Siklus II}

\begin{tabular}{|c|c|c|c|c|}
\hline \multirow{2}{*}{ No } & \multirow{2}{*}{ Nama } & \multicolumn{3}{|c|}{ Tindakan I } \\
\cline { 3 - 5 } & & Pra Siklus & $\begin{array}{c}\text { Siklus } \\
\text { I }\end{array}$ & Siklus II \\
\hline 1 & E1 & 30 & 50 & 90 \\
\hline 2 & E2 & 80 & 75 & 90 \\
\hline 3 & E3 & 40 & 75 & 80 \\
\hline 4 & E4 & 45 & 80 & 85 \\
\hline 5 & E5 & 25 & 50 & 75 \\
\hline 6 & E6 & 55 & 75 & 80 \\
\hline 7 & E7 & 50 & 55 & 55 \\
\hline 8 & E8 & 45 & 40 & 75 \\
\hline 9 & E9 & 75 & 75 & 90 \\
\hline 10 & E10 & 50 & 80 & 85 \\
\hline 11 & E11 & 75 & 80 & 90 \\
\hline 12 & E12 & 80 & 80 & 95 \\
\hline 13 & E13 & 75 & 95 & 100 \\
\hline 14 & E14 & 85 & 85 & 100 \\
\hline 15 & E15 & 75 & 85 & 100 \\
\hline
\end{tabular}




\begin{tabular}{|c|c|c|c|c|}
\hline 16 & E16 & 30 & 80 & 80 \\
\hline 17 & E17 & 35 & 50 & 85 \\
\hline 18 & E18 & 75 & 80 & 75 \\
\hline 19 & E19 & 45 & 50 & 95 \\
\hline 20 & E20 & 75 & 75 & 90 \\
\hline 21 & E21 & 55 & 55 & 90 \\
\hline 22 & E22 & 55 & 70 & 80 \\
\hline \multicolumn{2}{|c|}{ Jumlah } & 1255 & 1540 & 1885 \\
\hline \multicolumn{2}{|c|}{ Rata-rata } & 57,04 & 70 & 85,68 \\
\hline \multicolumn{2}{|c|}{ Presentase } & $40,9 \%$ & $68,18 \%$ & $95,45 \%$ \\
\hline
\end{tabular}

Proses pembelajaran dengan menggunakan model Contextual teaching and learningyang dilakukan guru sudah sangat baik dari kegiatan awal sampai akhir pembelajaran. Sebelum melaksanakan pembelajaran guru mempersiapkan semua hal-hal yang diperlukan dalam pembelajaran dengan merancang langkahlangkah pembelajaran, metode pembelajaran, sumber, tekhnik pembelajaran, evaluasi dan menyiapkan media pembelajaran. Hal ini merupakan rancangan guru yang dipersiapkan untuk dituangkan dalam Rencana Pelaksanaan Pembelajaran dengan menggunakan model contextual teaching and learning. Selanjutnya dalam pelaksanaan pembelajaran guru membagi siswa kedalam beberapa kelompok untuk melakukan sebuah praktikum dimana merupakan sebuah langkah awal siswa untuk memulai pembelajaran dengan melakukan kegiatan langsung untuk menemukan konsep materi pembahasan.
Berdasarkan hasil pengamatan yang dilakukan dalam proses pembelajaran bahwa pelaksanaan kegiatan pembelajaran dengan menggunakan model Contextual teaching and learning telah dilaksanakan dengan efektif. Hasil pengamatan pada kegiatan pembelajaran siklus I tindakan I, tindakan II, diperoleh hasil pengamatan pada aktivitas guru dimana masih ada aspek yang belum terlaksana dengan baik dalam pembelajaran dan belum maksimal.Hasil pengamatan siklus I diantaranya guru tidak menyampaikan tujuan dari pembelajaran yang akan dilaksanakan, dalam memberikan motivasi guru belum melaksanakan dengan baik sehingga masih banyak siswa yang kurang antusia dalam pembelajaran. Guru dalam mengkondisikan siswa masih banyak siswa yang susah untuk diatur sehingga pembelajaran belum kondusif, dalam kegiatan melakukan tanya jawab disini guru kurang memperhatikan siswa lainnya dan guru masih berpusat pada siswa tertentu saja dalam memberikan 
pertanyaan, sehingga terlihat siswa lainnya yang tidak aktif dalam pembelajaran.

Selain itu pada aspek kegiatan pembentukkan kelompok dan pemberian tugas untuk kelompoknya guru kurang jelas dalam menyampaikannya dan kurang maksimal sehingga masih banyak siswa yang tidakpaham dalam kelompoknya untuk mengerjakan tugas yang diberikan oleh gutu, kemudian dalam memberikan bimbingan pada setiap kelompok guru masih kurang dalam pemberian bimbingan sehingga masih banya siswa yang belum mendapat penjelasan dari guru dan masih bingung dapat memahami materi tersebut. Pada kegiatan akhir, berdasarkan hasil pengamatan siklus I dalam kegiatan membimbing siswa dalam menyimpulkan pembelajaran guru masih kurang mendorong siswa untuk menyampaikan hasil kesimpulan.

Selanjutnya pada siklus II hasil pengamatan kegiatan guru pembelajaran siklus I tindakan I, tindakan II, diperoleh hasil kegiatan pembelajaran mengalami peningkatan.Aspek-aspek kegiatan pembelajaran telah terlaksanakan secara efektif.Namun ada beberapa aspek yang masih belum maksimal dalam pelaksanaannya diantaranya dalam mengkondisikan siswa masih terdapat beberapa siswa yang belum kondusif dan dalam membimbing siswa dalam diskusi masih kurang jelas sehingga masih ada siswa yang kebingungan dalam mengerjakan tugas kelompoknya.

Berdasarkan hasil pengamatan kegiatan pembelajaran siklus I dan siklus II dapat disimpulkan bahwa kegiatan guru dalam pembelajaran dengan menggunakan model Contextual teaching and learning meningkat. Artinya guru sudah mampu menerapkan model Contextual teaching and learning pada pembelajaran IPA Materi Penerapan Konsep Energi Gerak pada siswa kelas III SD Negeri 3 Ngabenrejo Kecamatan Grobogan Kabupaten Grobogan.

Berdasarkan pengolahan data hasil evaluasi, ditemukan bahwa kemampuan Hasil belajar siswa pada pembelajaran IPA Materi Penerapan Konsep Energi Gerak mengalami peningkatan dari sebelum menggunakan model Contextual teaching and learning. Pada kondisi awal ditemukan bahwa tingkat hasil belajar siswa pada Materi Penerapan Konsep Energi Gerak masih rendah disebabkan karena pembelajaran yang disajikan masih bersifat konvensional, guru kurang melibatkan siswa secara langsung dalam pembelajaran, dalam menyajikan pembelajaran guru hanya mengendalikan buku semata oleh karena itu siswa hanya 
sebatas tahu tanpa memahami materi yang diajarkan. Sehingga kemampuan pemahan konsep siswa rendah terhadap materi yang diajarkan.Oleh karena itu peneliti berusaha mencari solusi untuk memecahkan masalah tersebut, solusi yang digunakan peneliti menerapkan model Contextual teaching and learning pada pembelajaran IPA Materi Penerapan Konsep Energi Gerak.

Model Contextual teaching and learning merupakankonsep belajar yang membantu guru dalam mengaitkan antara materi yang dipelajarinya dengan situasi dunia nyata siswa dan mendorong siswa membuat hubungan antara pengetahuan yang dimilikinya dengan penerapannya dalam kehidupan sehari-hari, pembelajaran dengan menggunakan model CTL ini siswa di tuntut untuk menemukan sendiri konsep pembahasan materi yang sedang disampaikan melalui kegiatan langsung yang dilakukan oleh siswa sehingga kegiatan tersebut membangun konsep pada siswa itu sendiri dan akan meningkatkan Hasil belajar siswa. peningkatan hasil evaluasi kondisi awal dan setelah menerapkan model contextual teaching and learning. Pada kondisi awal dari 22 orang siswa hanya 9 orang siswa yang mencapai ketuntasan belajar dan nilai ratarata siswa yang diperoleh hanya 57,04 dengan ketuntasan klasikal sebesar 40,9\% yang berada pada kategori rendah. Sedangkan, pada siklus I dari 22 orang siswa terdapat 15 orang siswa yang mencapai mastery learning dan nilai ratarata siswa sebesar 70 dengan ketuntasan klasikal 68,18\% yang berada pada kategori sedang. Kemudian, pada siklus II dari 22 orang siswa terdapat 21 orang siswa yang mencapai mastery learning dan nilai ratarata siswa sebesar 85,58 dengan ketuntasan klasikal 95,45\% yang berada pada kategori sangat tinggi.

Setelah peneliti melakukan pembelajaran dengan menggunakan model Contextual teaching and learning, kemampuan Hasil belajar siswa kelas III SD Negeri 3 Ngabenrejo Kecamatan Grobogan Kabupaten Grobogan meningkat terbukti dari peningkatan hasil evaluasi tiap tindakan. Pada proses pembelajaran siswa sangat antusias dan aktif dalam mengikuti kegiatan proses pembelajaran. Maria Lorin (2013), dengan judul "peningkatan aktivitas siswa pembelajaran Iearning menggunakan model contextual teaching and learning (CTL) kelas IV SDN 10 Bonti".Membuktikan bahwa penerapan model Contextual teaching and learningdapat mempengaruhi aktivitas siswa dalam belajarpembelajaran learning. 
Penggunaan model Contextual teaching and learningmenuntut siswa menemukan konsep sendiri dengan melakukan kegiatan langsung dalam pembelajaran. Sehingga setelah siswa mengikuti pembelajaran dengan melakukan suatu kegiatan praktikum dalam kelompok beljarnya siswa mampu melakukan dan dapat menyimpulkan konsep dari materi yang sedang dibahas melalui kegiatan tersebut, siswa mampu bekerja sama dan berinteraksi dalam kelompoknya.. Sehingga CTL ini memberikan kesempatan besar kepada siswa untuk mengembangkan kemampuan berpikirnya dan mengembangkan kemampuan membangun konsep sendiri melalui suatu kegiatan langsung yaitu praktikum dalam kelompok belajar yang menuntut siswa harus bekerja sama, berinteraksi, dan menyelesaikan masalah secara bersama-sama kemudian menemukan konsep dari suatu pembahasan materi dalam praktikum tersebut. Dalam kegiatan langsung tersebut siswa dapat mengolah kemampuannya untuk menyelesaikan permasalahan dalam praktikum kemudian bekerja sama dalam menemukan konsep permasalahan materi dan siswa mampu menjelaskan konsep materi yang ditemukan dalam kegiata praktikum tersebut dengan menggunakan bahasa sendiri. Oleh karena itu siswa dapat meningkatkan Hasil belajarnya melalui serangkaian kegiatan pembelajaran dalam model CTL dan siswa dalam pembelajaran akanlebih baik dari pembelajaran sebelum menggunakan model Contextual teaching and learning.

\section{PENUTUP}

\section{Simpulan}

Penerapan model pembelajaran contextual teaching and learning pada mata pelajaran IPA di SD Negeri 3 Ngabenrejo pada kelas III mampu meningkatkan hasil belajar IPA siswa. Bagi siswa kelas III di SD Negeri 3 Ngabenrejo belajar dengan melakukan suatu percobaan dan mereka menentukan konsep materi dalam percobaan merupakan pembelajaran yang sangat baru dan membantu mereka dalam memahami materi pembelajaran IPA. Berdasarkan hasil observasi guru pada siklus I diperoleh nilai $68,18 \%$ dengan rata-rata 70 dan mengalami peningkatan pada siklus ke II dengan diperoleh nilai $95,45 \%$ dengan rata-rata 85,68 maka dengan hasil tersebut pembelajaran dengan menggunakan model pembelajaran contextual teaching and learning ini telah menigkatkan hasil belajar IPA siswa kelas III berdasarkan 
bimbingan dan pengarahan guru dalam proses pembelajaran.

Model pembelajaran contextual teaching and learning dapat meningkatkan hasil belajar IPA dalam mata pembelajaran IPA materi Penerapan Konsep Energi Gerak di kelas III SD Negeri 3 Ngabenrejo. Hal ini dapat dilihat dari hasil pemahaman siswa pada prasiklus dengan nilai 40,09\% dengan rata-rata 57,04 siswa yang tuntas 9 dan yang tidak tuntas 13 siswa, setelah dilakukan siklus I dengan 2 tindakan terjadi peningkatan ketuntasan hasil belajar dengan nilai $68,18 \%$ dengan ratarata 70 sebanyak 15 siswa tuntas dan 7 belum tuntas. Pada siklus II ketuntasan belajar meningkat sebesar $95,45 \%$ dengan rata-rata 85,68 sebanyak 21 siswa tuntas dari 22 siswa kelas III SD Negeri 3 Ngabenrejo.

\section{DAFTAR PUSTAKA}

Aunurrahman.(2012).Belajar dan Pembelajaran. Bandung: Alfabeta.

Dasari.(2002). Strategi Belajar Mengajar.Jakarta :Rineka Cipta.

Hamdani, O. (2002). Perencanaan Pengajaran Berdasarkan Pendekatan Sistem. Jakarta :BumiAksara.

Hosnan.(2014).Pendekatan Saintifik dan kontekstual dalam Pembelajaran Abad 21. Bogor: Ghalia Indonesia.

IbnuBadar, T. (2014).Mendesain Model Pembelajaran Inovatif, Progresif, dan Kontekstual ,Jakarta: Prenadamedia group.

Johnson B, E. (2014). Contextual Teaching and Learning. Bandung: Kaifa.

Komalasari, K. (2010). Pembelajaran Kontekstual Konsepdan Aplikasi. Bandung: PT RefikaAditama.

Lorin, Maria. (2013). Peningkatan Aktivitas Siswa Pembelajaran Learning Menggunakan Model Contextual Teaching And Learning (CTL) Kelas IV SDN 10 Bonti. Pontianak: Universitas Tanjungpura

Marsiti. (2008). Efektivitas Penerapan Metode Contextual Teaching And Learning (CTL) dalam Meningkatkan Motivasi Belajar Siswa Kelas III SDN Wonosobo. Semarang:

UNNES. 
Mulyasa.(2012). Manajemen Pendidikan Karakter. Jakarta: PT BumiAksara. (2016). Pengembangan Dan Implementasi Kurikulum 2013 Bandung: Remaja

Rosdakarya

Nugroho, Deni. (2013). Upaya Meningkatkan Kemampuan Berkomunikasi dan

Pemahaman Konsep Siswa Kelas VIIIB Smp N 3 Ngawen Pada Pembelajaran

Keterampilan Elektronika Melalui Pendekatan Contextual Teaching And Learning (CTL)

Tahun Pelajaran 2013/2014. Yogyakarta: UNY.

Rifai, Catharina. (2009). Psikologi Pendidikan. Semarang : UPT UNNES Press

Ridwan.(2010). Dasar-dasar Statistika. Bandung: Alfabeta.

Putra, S R. (2013). Desain Belajar Mengajar Kreatif Berbasis Sains. Yogyakarta: Diva Press.

Rustaman, dkk. (2005). Strategi Belajar Mengajar .Malang : UM Press.

Sanjaya.(2009).Penelitian Tindakan Kelas. Jakarta: Kencana Prenada Media.

Sudjana, N. (2014). Penilaian Hasil Proses Belajar Mengajar. Bandung: PT Remaja

Rosdakarya.

Suryobroto.(2010). Dasar-dasar Pendidikan. Jakarta: Rhineka Cipta.

Susanto, A. (2013). Teori Belajar dan Pembelajaran di SD. Jakarta: Kencana Prenada

Media Group.

Suyadi.(2010). Penelitian Tindakan Kelas.Yogyakarta: Diva Press.

Syaefudin, U. (2009). Inovasi Pendidikan.Bandung: Alfabeta.

Syah, Nuhubbin. (2010). Psikologi Pendidikan, Bandung: Remaja Rosdakarya.

Trianto.(2012). Pembelajaran Terpadu. Jakarta: Bumi Aksara.

Wiriaatmadja, R. (2009). Metode Penelitian Tindakan Kelas. Bandung: PT Remaja

Rosdakarya. ,

Wiyani, A. N. (2013). Manajemen Kelas. Yogyakarta: Ar-ruzz Media. 